\title{
Immunomodulatory effect of petroleum ether extract and ethyl acetate fraction of bengkoang (Pachyrhizus erosus (L.) Urban) in vitro
}

\author{
Tanti Azizah Sujono ${ }^{\text {, Arief Nurrochmad }}{ }^{*}$, Endang Lukitaningsih ${ }^{3}$, Agung Endro Nugroho $^{2}$
}

1. Department of Pharmacology and Clinical Pharmacy, Faculty of Pharmacy, Universitas Muhammadiyah Surakarta, Jl. Ahmad Yani, Pabelan, Kartasura, Surakarta 57162, Indonesia

2. Department of Pharmacology and Clinical Pharmacy, Faculty of Pharmacy, Universitas Gadjah Mada, Sekip Utara Yogyakarta 55281, Indonesia

3. Department of Pharmaceutical Chemistry, Faculty of Pharmacy, Universitas Gadjah Mada, Sekip Utara Yogyakarta 55281, Indonesia

\begin{tabular}{l}
\hline Info Article \\
\hline Submitted: $09-05-2021$ \\
Revised: $10-11-2021$ \\
Accepted: $16-12-2021$ \\
*Corresponding author \\
Arief Nurrochmad \\
Email: \\
ariefnr@ugm.ac.id
\end{tabular}

ABSTRACT

Bengkoang (Pachyrhizus erosus (L.) Urban) contains phytosterol and the isoflavone daidzein, which are thought to have immunomodulatory activity. There have been no studies reporting on the immunomodulatory effects of bengkoang extract containing polar and semi-polar compounds, such as phytosterols and isoflavone-like compounds. The objective of this study was to evaluate the immunomodulatory effects of bengkoang extracts, including petroleum ether extract (PEE), methanol extract (ME), and the ethyl acetate fraction (EAF) of bengkoang, in vitro. The immunomodulatory effects of PEE, ME, and EAF of bengkoang were determined according to the phagocytic activity of macrophages based on phagocytosis of latex beads, lymphocyte proliferation, and detection of cytokine production of tumor necrosis factor- $\alpha$ (TNF- $\alpha$ ) interleukin-6 (IL-6), and interleukin-10 (IL-10) levels. Results: The phagocytic index and phagocytic capacity of ME, PEE, and EAF of bengkoang on macrophage cells were significantly increased $(p<$ 0.05 ), whereas on lymphocyte proliferation, ME showed a trend of increasing activity $(\mathrm{p}<0.05)$. On the other hand, the PEE effect showed a decreasing trend of activity, and the others had no significant effect on lymphocyte proliferation ( $p>0.05$ ), and ME of bengkoang enhanced the levels of the cytokines TNF- $\alpha$ and IL- 6 . In contrast, PEE and EAF of bengkoang decreased TNF- $\alpha$ and IL- 6 levels compared with the control group. All of the bengkoang extracts decrease the production of the anti-inflammatory cytokine IL-10. In conclusion, this study showed that PEE, ME, and EAF of bengkoang could increase the non-specific immune response (phagocytic activity) but had a lesser effect on the specific immune response (lymphocyte proliferation). The ME of bengkoang acts as an immunostimulant by increasing the levels of the inflammatory cytokines TNF- $\alpha$ and IL- 6 and decreasing those of the antiinflammatory cytokine IL-10. Further investigation of in vivo immunomodulatory effects is needed to determine its effect on systemically innate and adaptive immune responses.

Key words: Pachyrhizus erosus L., immunomodulatory, phagocytic activity, lymphocyte proliferation, cytokines, in vitro

\section{INTRODUCTION}

Suppression of the body's immune system can be caused by infectious disease, lifestylerelated stress, which can trigger an immune system disorder, and also the presence of an immunesystem-related disease. For these reasons, substances known as immunomodulators are needed to regulate the immune system. Immune responses are grouped into innate (non-specific) and adaptive (specific). Innate immunity provides rapid protection against infection, whereas adaptive immunity responds more slowly but 
provides more specialized protection. The epithelial barrier, dendritic cells, phagocytes, mast cells, NK (natural killer) cells, and the complement system are responsible for non-specific immunity, whereas there are two types of adaptive immunity, namely humoral (for extracellular pathogens) and cellular (cell-mediated immunity). Antibodies produced by B lymphocytes play a role in humoral immunity (Abbas et al., 2018), whereas cellmediated immunity involves $\mathrm{T}$ lymphocytes directed at intracellular pathogens.

At present, public interest in the use of herbal medicine as an agent that can modulate the immune system in preventing infection is increasing. There are two types of immunomodulators, namely synthetic and natural. Groups of compounds such as flavonoids, polysaccharides, lactones, alkaloids, diterpenoids, and glycosides found in some plants have been reported to be responsible for immunomodulatory effects (Jantan et al., 2015). Immunomodulators derived from natural food ingredients are less toxic than and do not show significant side effects (Schepetkin and Quinn, 2006). There are several lines of evidence supporting the modulation and activation of immune function and the immune response by food intake (El-gamal et al., 2011; Kaminogawa and Nanno, 2004); Sharma and Rangari, 2016). One plant that could be developed as an immunomodulator is bengkoang, an edible root vegetable that contains 2.1-10.7 g starch, high fiber, around $84 \%$ water, little protein, and lipids. Bengkoang contains vitamin $\mathrm{C}$ and potassium. The caloric content is quite low (39 kcal/100 g), which allows bengkoang to be consumed as a health food (Noman et al., 2007). A previous study identified some of the chemical compounds in bengkoang. The nonpolar extract (petroleum ether extract (PEE)) of bengkoang contains approximately $2.76 \%$ phytosterol. $\beta$-sitosterol and stigmasterol are the main components of phytosterol, with a $65: 35$ ratio of $\beta$-sitosterol to stigmasterol, while the ethyl acetate fraction (EAF) of bengkoang contains isoflavones in the form of daidzein, daidzein-7-0- $\beta$ glucopyranose, 5-hydroxy-daidzein-7-0- $\beta$ glucopyranose, and 8.9 furanyl-pterocarpan-3-ol, which are efficacious as antioxidants and tyrosinase inhibitors (Lukitaningsih, 2012; Lukitaningsih and Ulrike, 2014).

A previous study indicated that isoflavones have immunomodulatory effects. Dose-dependent administration of the isoflavone daidzein increased the number of total leukocyte cells, monocyte and lymphocyte counts, hemagglutinin titers, and the phagocytic index (Dwiecki et al., 2009; Maji et al., 2014). $\beta$-sitosterol has immunostimulant activity in vitro by increasing the phagocytic index and capacity of macrophages (Wahdaningsih et al., 2018). Studies published by Kumalasari et al. showed that bengkoang fiber extract (BFE) had immunomodulatory activity by stimulating phagocytic activity and increasing the production of TNF- $\alpha$ and interleukin (IL) -6 by cells of the cell line J774.1 and peritoneal macrophages in rats. Moreover, BFE reduced the production of IgM from human hybridoma HB4C5 cells as well as the production of IgM, IgG, and IgA from rat splenocytes (Kumalasari et al., 2013; Kumalasari et al., 2014). This study shows that bengkoang tuber has the potential to be developed as a medicinal plant with efficacy as an immunomodulator.

However, there have been no studies about the immunomodulatory effects of PEE containing $\beta$-sitosterol and EAFs of methanol extract (ME) of bengkoang tubers containing semi-polar isoflavone compounds. Immunomodulatory study are still limited to fiber extracts. Therefore, this in vitro study was performed to evaluate the immunomodulatory effects of PEE and the EAF of ME of bengkoang on the phagocytic activity of macrophages, lymphocyte proliferation, and cytokine production.

\section{MATERIAL AND METHODS}

\section{Collection and authentication of plants}

Bengkoang tubers were collected from Prembun Kebumen, Central Java, Indonesia. Bengkoang (Pachyrhizus erosus) plants were identified and authenticated by Dr. Djoko Santosa, Assistant Professor in the Department of Pharmaceutical Biology, Faculty of Pharmacy, Universitas Gadjah Mada, Yogyakarta, Indonesia (voucher specimen number: UGM/FA/2254/M/03/02).

\section{Extraction and fractionation of Bengkoang}

Bengkoang ( $50 \mathrm{~kg}$ ) was peeled and washed with water, then dried at $40^{\circ} \mathrm{C}-50^{\circ} \mathrm{C}$ in an oven for two days and blended into a powder. Fine powder (4.3 kg) was extracted using petroleum ether, and the filtrate was concentrated in a vacuum evaporator. The residue was extracted using methanol to trace semi-polar and polar compounds. The filtrate was concentrated using a rotary evaporator. The concentrated ME was combined with water and then partitioned with ethyl acetate. The EAF was then concentrated with a vacuum evaporator. 


\section{Animals}

Male BALB/c mice, eight weeks old, weighing 20-30 g, aged six to eight weeks, were obtained from the Animal Center of Pharmacology and Toxicology Laboratory, Universitas Gadjah Mada. All animals were acclimatized for one week before experimentation and housed in an animal room with a temperature of $(22 \pm 3)^{\circ} \mathrm{C}$ and humidity of $60 \%$ under a 12 -hour light/dark cycle. A standard pelleted basal diet and water were provided ad libitum. Animals were randomized into experimental and control groups. All procedures were approved by the Institutional Animal Ethics Committee of the Integrated Research and Testing Laboratory, Universitas Gadjah Mada (number 00073/04/LPPT/VII/2018).

\section{Phagocytic assay}

Male BALB/c mice were sacrificed, then the skin of the abdomen was opened and cleaned of the peritoneal sheath with $70 \%$ ethanol. Ten milliliters of cold RPMI 1640 (Roswell Park Memorial Institute) medium (GIBCO, USA) was injected into the peritoneal cavity, and pressure was applied slowly for approximately 3 minutes. The peritoneal fluid was removed with an injection syringe from a distant part of the intestine away from any fat. The peritoneal fluid was centrifuged at $1,200 \mathrm{rpm} 4^{\circ} \mathrm{C}$ for 10 minutes. The supernatant was removed, and $3 \mathrm{~mL}$ of complete media (containing FBS 10\%) was added to the pellet. The cells were counted and then suspended in complete medium to obtain a density of $2.5 \times 10^{6}$ cells $/ \mathrm{mL}$. The cell suspension was then cultured on coverslips in 24-well microplates. Each well was given $200 \mu \mathrm{L}$ of the cell suspension $\left(5 \times 10^{5}\right.$ cells $)$.

Cells were incubated at $37^{\circ} \mathrm{C}$ in a $5 \% \mathrm{CO}_{2}$ incubator overnight. Subsequently, the media was removed and the cells washed once with RPMI media. Then $1 \mathrm{~mL}$ of bengkoang extract was added at concentrations of 50,100 , and $200 \mu \mathrm{g} / \mathrm{mL}$, while standards of levamisole (PT Konimex, Indonesia), daidzein (Santa Cruz Biotechnology, Santa Cruz, CA, USA), and $\beta$-sitosterol (Santa Cruz Biotechnology, Santa Cruz, CA, USA) were included at concentrations of $12.5,25$, and $50 \mu \mathrm{g} / \mathrm{mL}$, as well as a media control, in triplicate wells. The plates were incubated in an incubator in a 5\% $\mathrm{CO}_{2}$ atmosphere at $37^{\circ} \mathrm{C}$ for 1 hour. Latex beads (polystyrene $3.0 \mu \mathrm{m}$, Sigma Chemical Co., St Louis, MO, USA) were suspended in complete medium to a density of 2.5 $\times 10^{7}$ cells $/ \mathrm{mL}$. A total of $300 \mu \mathrm{L}$ of a suspension of latex beads was added to each well, then the plate was incubated in an incubator in a $5 \% \mathrm{CO}_{2}$ atmosphere at $37^{\circ} \mathrm{C}$ for 60 minutes. The cells were then washed with phosphate buffered saline three times to remove non-phagocytic latex beads, then dried at room temperature. The cells were fixed with methanol for 30 seconds, which aims to keep the cellular protein attached to the coverslip and prevent the cells from being damaged during the coloring process (Giemsa) (Woronzoff-Dashkoff, 2002). Then, the methanol was removed and dried, and the coverslip was painted with Giemsa $20 \%$ (v/v) for 30 minutes. Giemsa (Merck, Darmstadt, Germany) staining gives a dark purple color to the cell nucleus and a red-blue to the cytoplasm. The plate was washed with distilled water 4-5 times, then dried at room temperature (Nurrochmad et al., 2015). Macrophages that phagocytosed latex beads were counted using a microscope with a magnification of $400 \times$.

Macrophage phagocytic parameters were measured by calculating the phagocytic capacity and phagocytic index (Jensch et al., 2006). The phagocytic index (PI) is the number of latex beads that are phagocytosed by macrophages compared to the number of active macrophages (100), while the phagocytic capacity is the ratio of the number of macrophages that phagocytosed latex beads to the number of 100 macrophages multiplied by 100 .

\section{Lymphocyte proliferation assay}

Male BALB/c mice were sacrificed, then the spleen tissue was isolated aseptically, after which it was placed in a $50-\mathrm{mm}$ petri dish containing RPMI 1640 to obtain a suspension of lymphocytes in the medium, then centrifuged at $1200 \mathrm{rpm}$ and $4^{\circ} \mathrm{C}$ for 10 minutes. The pellet was separated from the supernatant and suspended in tris-buffered ammonium chloride to lyse the erythrocytes and allowed to stand at room temperature for 5 minutes. The centrifugation was repeated for 10 minutes, and the supernatant was discarded. Pellets were suspended in complete medium. Next, the cells were counted and suspended in complete medium to a density of $1.5 \times 10^{6}$ cells $/ \mathrm{mL}$, and 100 $\mu \mathrm{L}$ of cell suspension was added to each well of a 96-well plate, and $2 \mu \mathrm{L} /$ well phytohemagglutinin (PHA) was added. The plates were then incubated in an incubator in a $5 \% \mathrm{CO}_{2}$ atmosphere at $37^{\circ} \mathrm{C}$ for 24 hours. The bengkoang extract; levamisole, $\beta$ sitosterol, and daidzein standards with concentrations of $12.5,25,50,100$, and $200 \mu \mathrm{g} / \mathrm{mL}$; and a media control were then added and incubated for 48 hours. Furthermore, $10 \mu \mathrm{L}$ MTT [3-(4,5-dimethylthiazol-2-yl)-2,5-

diphenyltetrazolium-bromide] was added to each 
well at a concentration of $5 \mathrm{mg} / \mathrm{mL}$, then incubated in an incubator with $5 \% \mathrm{CO}_{2}$ at $37^{\circ} \mathrm{C}$ for 4 hours. The MTT assay method employs the principle of colorimetric yellow salt tetrazolium reduced by the dehydrogenase enzyme system in the living cell mitochondria to form purple formazan. Next, the stop reagent (10\% SDS) in $50 \mu \mathrm{L} 0.01 \mathrm{~N} \mathrm{HCl}$ was added to each well. The addition of SDS lyses the cells, and the crystals will dissolve, resulting in a colored solution. Lymphocyte proliferation was read with a microplate reader at a wavelength of $550 \mathrm{~nm}$ based on absorbance (optical density) (Nurrochmad et al., 2015).

\section{Analysis of cytokine production}

Lymphocyte cells were isolated as per the procedure above (lymphocyte proliferation) with a lymphocyte cell density $1 \times 10^{7}$ cells $/ \mathrm{mL}$. PHA was added to the lymphocytes cells at $2 \mu \mathrm{L} /$ well then cultured in 96-well microtiter plates and incubated at $37^{\circ} \mathrm{C}$ in an incubator with $5 \% \mathrm{CO}_{2}$ for 24 hours. After incubation, $100 \mu \mathrm{L}$ samples of bengkoang extract and standard levamisole, $\beta$-sitosterol, and daidzein were added to each well and incubated again for 48 hours, then centrifuged at $1000 \mathrm{rpm}$ for 20 minutes at $2^{\circ} \mathrm{C}-8^{\circ} \mathrm{C}$. The supernatant was collected, and the assay was performed immediately. Cytokine analysis was performed using sandwich enzyme-linked immunosorbent assay kits (Fine Test, Wuhan Fine Biotech Co., Ltd., Wuhan, China) according to manufacturer's protocol.

\section{Statistical analysis}

Data from all experiments were expressed as the mean \pm standard error of the mean (SEM). The statistical analysis was performed using SPSS, Version 22 (Armonk, NY: IBM Corp.). One-way analysis of variance followed by the least significant difference test was used to assess the statistical significance of differences between values, and results were considered significant at ${ }^{*} p<0.05,{ }^{* *} p<0.01{ }^{* *} p<0.01$ relative to the control.

\section{RESULT AND DISCUSSION}

This study focuses on how bengkoang tuber extract can modulate immune cells specifically through macrophage phagocytosis and lymphocyte proliferation and the production of the cytokines TNF- $\alpha$, IL- 6 , and IL-10. The yields obtained from the extraction and fractionation of bengkoang, namely methanol extract (ME), EAF, and petroleum ether extract (PEE) were $34.00 \%, 4.78 \%$, and
$0.50 \%$, respectively. The results showed that methanol extract had a higher yield than petroleum ether extract and EAF, meaning that bengkoang tubers contained more polar compounds than nonpolar and semi-polar compounds.

\section{Effect of bengkoang extract on phagocytic activity}

To determine the effect of bengkoang extract on phagocytic activity, in vitro phagocytosis assays were performed, and the phagocytic activity of macrophage cells on latex beads particle was determined. Increased phagocytic activity of macrophages is characterized by an increase in the number of macrophages that phagocytose latex bead particles (phagocytic capacity) and an increase in the number of latex beads particles phagocytosed by macrophages (phagocytic index), (Figure 1).

These studies were carried out at three concentrations, 50,100, and $200 \mu \mathrm{g} / \mathrm{mL}$, and in control media. The results showed that PEE, $\mathrm{ME}$, and EAF of bengkoang significantly increased the phagocytotic capacity and phagocytotic index of macrophage cells compared with control cells $(p<0.05)$. The value of the phagocytotic capacity of macrophages from the three samples closest to the positive control of levamisole and standard daidzein and $\beta$-sitosterol (Figures 2 and 3).

Macrophages function mainly in early innate immune responses as part of the host defense mechanism (Muralidharan and Mandrekar, 2013). Phagocytosis of macrophages is a widely used method for screening active ingredients that affect the immune response (Jensch et al., 2006). The use of 3- $\mu \mathrm{m}$ latex beads, based on their similar size to that of bacteria, is in the range of $1-10 \mu \mathrm{m}$ and is also adjusted to the size of macrophages, which is 100-225 $\mu \mathrm{m}$ (Champion et al., 2008; Desjardins and Griffiths, 2003). Latex beads cannot be stained by Giemsa dyes and are therefore easy to observe (Desjardins and Griffiths, 2003). Phagocytosis testing of macrophages is carried out on macrophage cells isolated from the mouse peritoneal cavity. The peritoneal cavity is the fluidfilled abdominal cavity filled and is a gathering place for immune cells such as macrophages, B cells, and T cells (Ray and Dittel, 2010).

Nonpolar extract of bengkoang (PEE) can increase the phagocytic capacity and phagocytic index, an effect that may be due to the $\beta$-sitosterol content of PEE (Lukitaningsih, 2012). 


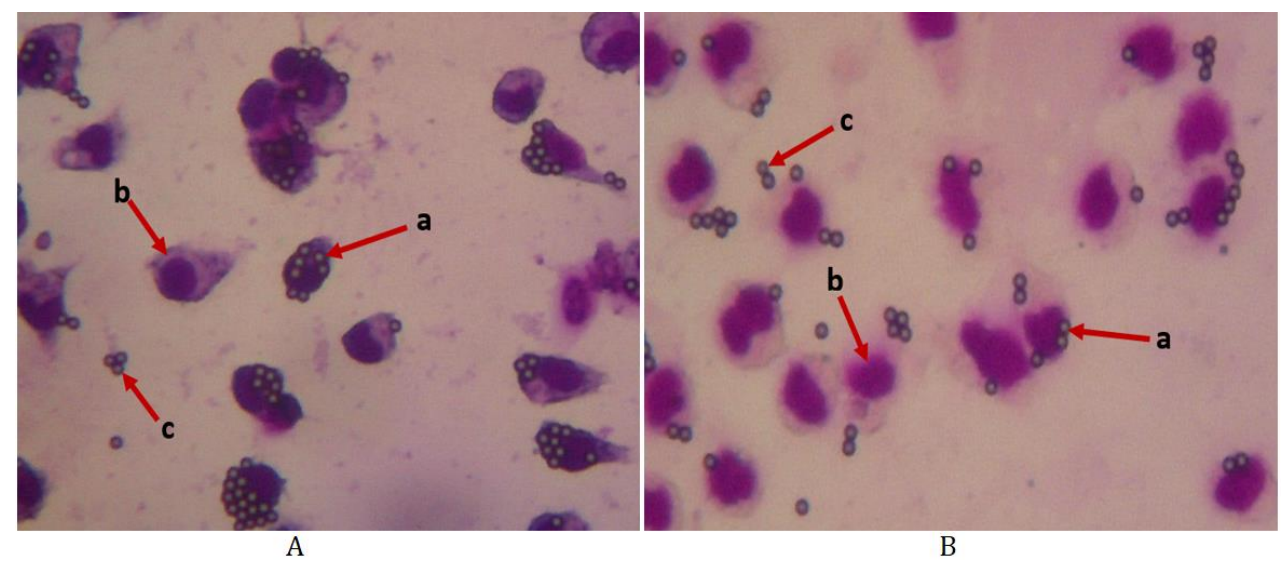

Figure 1. Macrophage eats latex beads (a), macrophage does not eat latex beads (b), latex beads (c). The macrophage activity in the treatment group (A) and the control cell group (B).
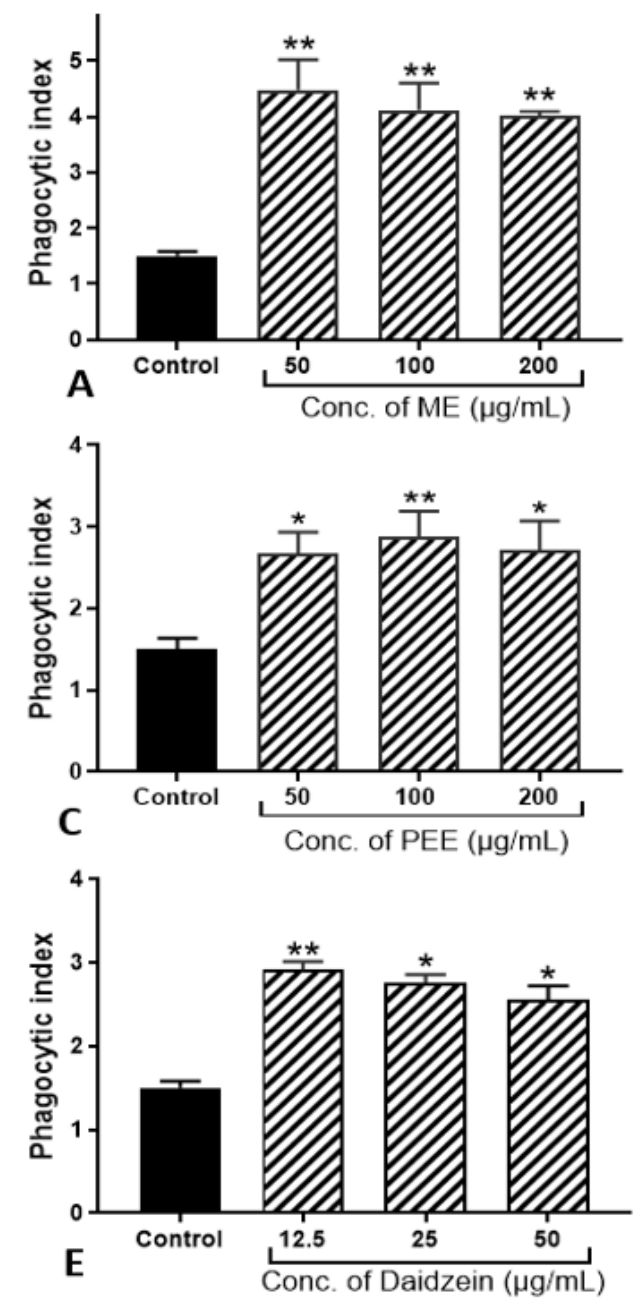
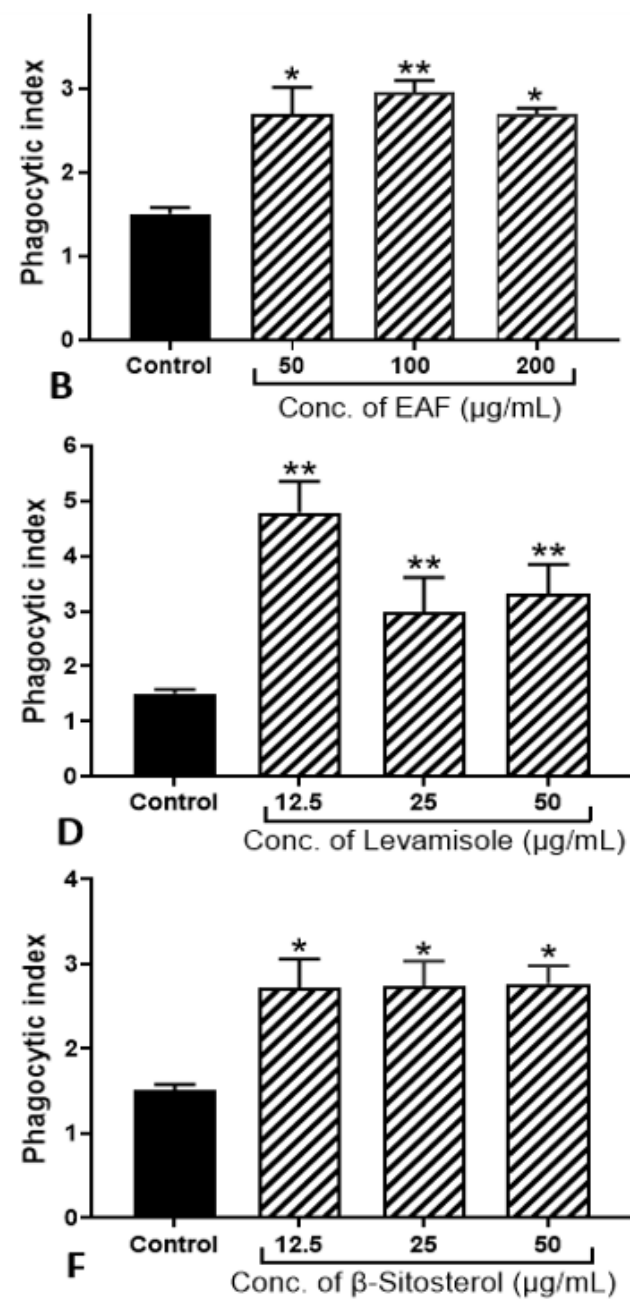

Figure 2. Effect of methanolic extract (ME), ethyl acetate fraction (EAF), and petroleum ether extract (PEE) of bengkoang on the phagocytic index of macrophages (mean $\pm \mathrm{SEM}, \mathrm{n}=3$ ). ${ }^{*} p<0.05,{ }^{* *} p<0.01$ were significantly different compared with the control. 

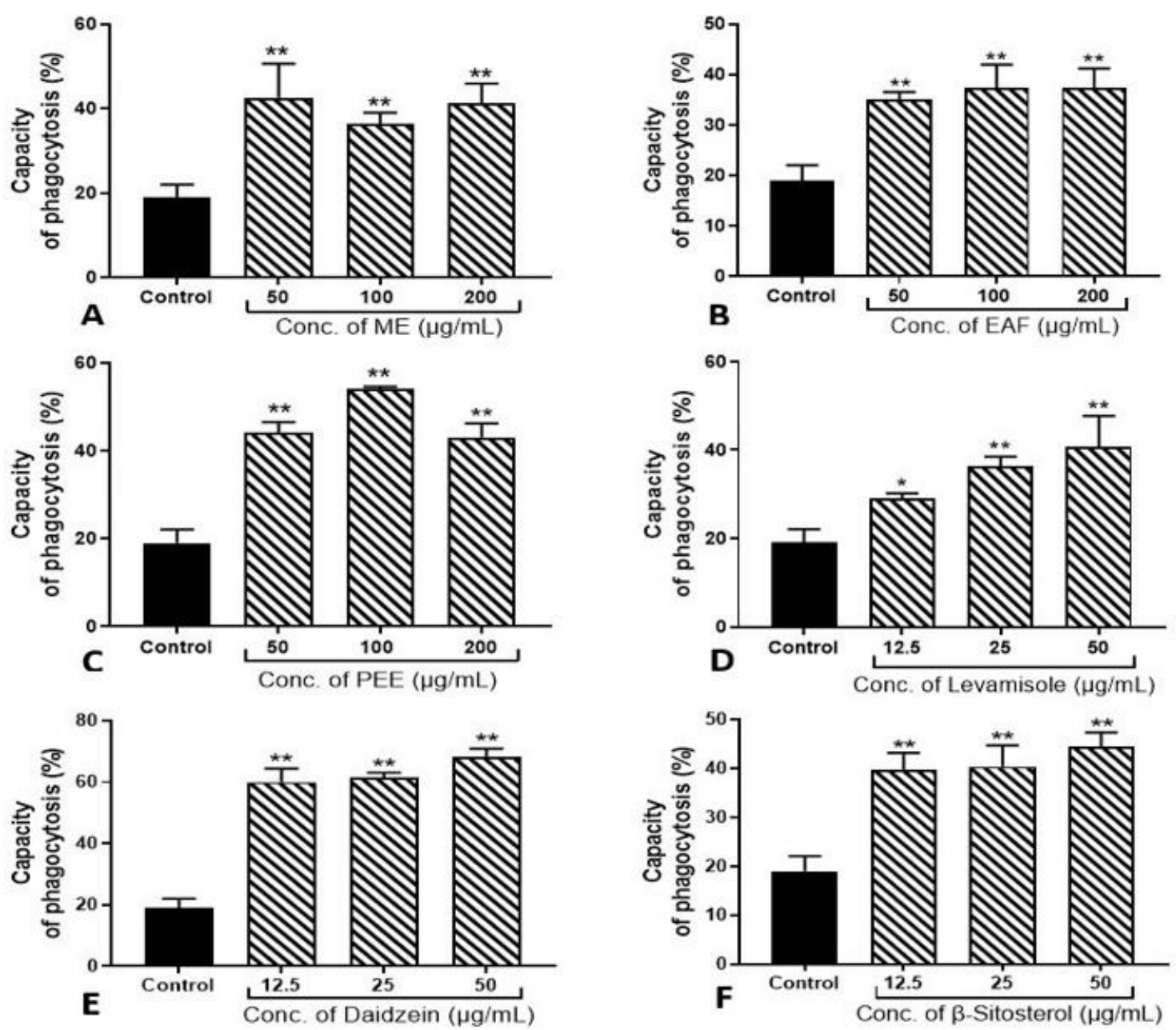

Figure 3. Effect of methanolic extract (ME), ethyl acetate fraction (EAF), petroleum ether extract (PEE) of bengkoang on the phagocytic capacity (data represent mean \pm SEM, $\mathrm{n}=3$ ). ${ }^{*} p<0.05,{ }^{* *} p<0.01$ were significantly different compared with the control.

This is in line with a previous report showing that $\beta$-sitosterol acts as an immunostimulant by increasing the index and capacity of phagocytosis of macrophages in vitro (Wahdaningsih et al., 2018). Moreover, the EAF of bengkoang increases the phagocytic index, and this effect may be due to the isoflavone content of EAF including, for example, daidzein. A prior study showed that daidzein acts as an immunomodulator by increasing the total number of leukocytes, monocytes, and lymphocytes; hemagglutinin titer; and phagocytic index (Maji et al., 2014). In this study, the effect on the phagocytic capacity of EAF was smaller than that of standard daidzein. This may be because, besides daidzein, EAF contains other isoflavones, which can reduce the phagocytic effect. As in the study of Maji et al., it shows that although daidzein and genistein are both in the flavonoid group in the form of isoflavones, they have opposing immunomodulatory effects Maji et al., 2014).

\section{Effect of bengkoang extract on lymphocyte proliferation}

This research used levamisole as a positive control. Levamisole (imidazothiazole) is indicated as an anti-helminthic and also has an immunomodulatory effect by inducing macrophages, $\mathrm{B}$ and $\mathrm{T}$ lymphocytes, and monocytes. Levamisole enhances macrophage phagocytosis at low concentrations and does not influence proliferation according to the MTT assay (Li et al., 2011). 

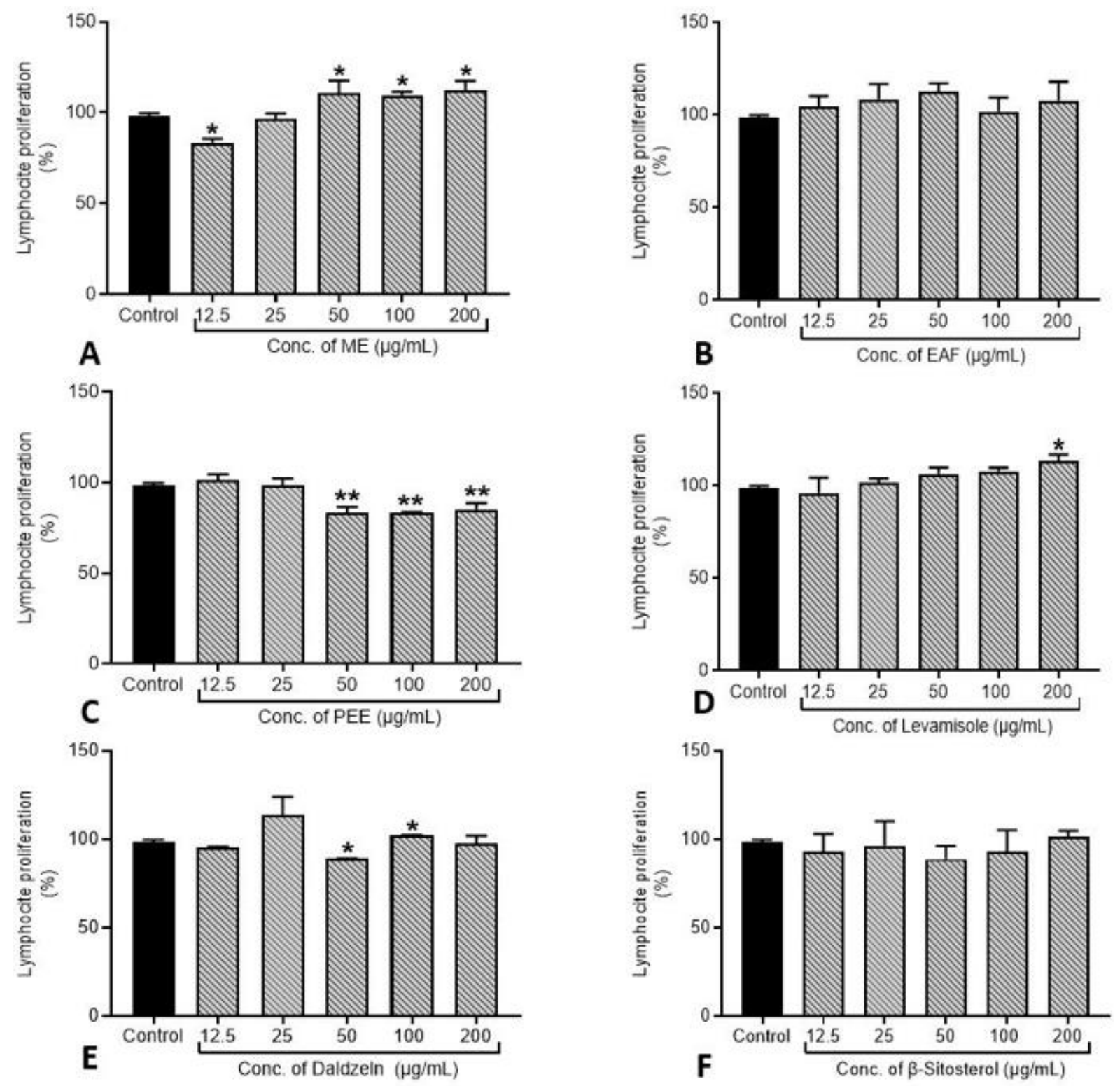

Figure 4. Effect of ME (methanol extract), EAF (ethyl acetate fraction), and PEE (petroleum ether extract) of bengkoang and standard ( $\beta$-sitosterol, daidzein, and levamisole) on mouse lymphocyte proliferation (data represent mean $\pm \mathrm{SEM}, \mathrm{n}=3$ ). ${ }^{*} p<0.05,{ }^{* *} p<0.01$ were significantly different compared with the control.

Levamisole can increase the phagocytic index in vitro (Findlay and Munday, 2000). The result shown that none of the extracts (ME, PEE, and EAF) were active against lymphocyte proliferation. The effect of ME exhibited a trend of increasing activity up to $200 \mu \mathrm{g} / \mathrm{mL}$ and the difference was significant $(\mathrm{p}<0.05)$. On the other hand, the PEE effect showed a decreasing trend of activity and the difference was significant $(\mathrm{p}<0.01)$. Meanwhile EAF, as well as daidzein and $\beta$-sitosterol, the compounds contained in bengkoang, had no significant effect on lymphocyte proliferation ( $p>0.05$ ) (Figure 4).

In the lymphocyte proliferation assay, phytohemagglutinin (PHA) was used to stimulate cell proliferation (Tsai et al., 2008). Increasing lymphocyte proliferation is a sign of the body's immune response to infection. Lymphocyte cells function to maintain specific immune responses, 

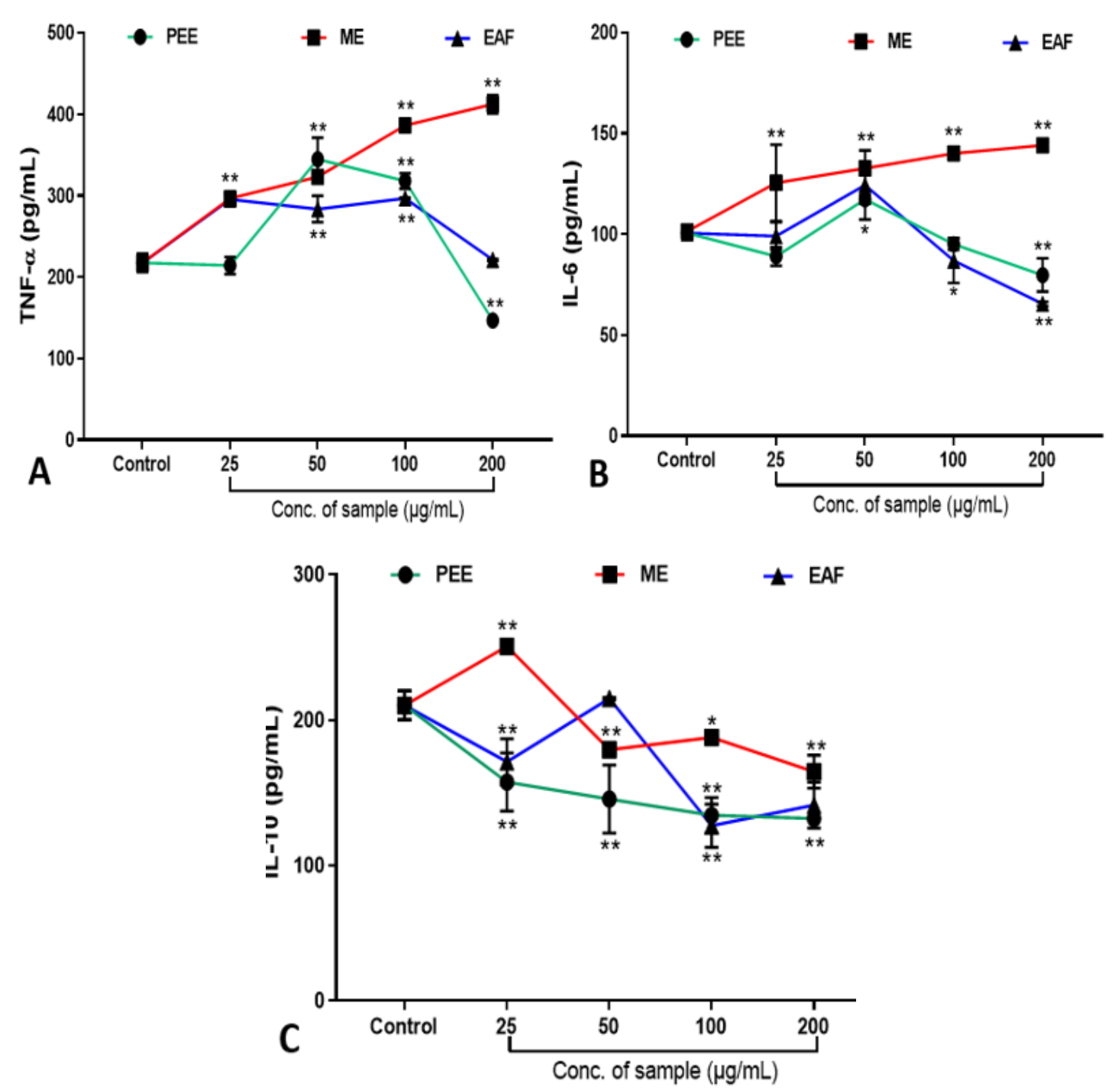

Figure 5. Effect of petroleum ether extract (PEE), methanol extract (ME), and ethyl acetate fraction (EAF) of bengkoang on TNF- $\alpha(\mathrm{a})$, IL-6 (b), and IL-10 (c) levels (data represent mean \pm SEM, $\mathrm{n}=3$ ). ${ }^{*} p<0.05,{ }^{* *} p$ $<0.01$ are significantly different compare with the control.

including cellular (related to T cells) and humoral (related to antibodies or B cells) immune responses (Abbas et al., 2018). The results of this study showed that ME and PEE of bengkoang influenced lymphocyte proliferation in vitro.

\section{Effect of bengkoang extract on cytokine production}

Stimulation of the innate immune system can contribute to host resistance against pathogenic threats (Kumalasari et al., 2013). Several mediators, inflammatory cytokines such as IL-1, IL6 , and TNF- $\alpha$, were secreted by activated macrophages to activate other cells to initiate the adaptive immune response (Aderem and Ulevitch, 2000). The effect of administration PEE, ME, and EAF of bengkoang on the levels of production of the cytokines TNF- $\alpha$, IL- 6 , and IL-10 in vitro can be seen in Figure 5 (data represent the mean \pm SEM, $n=3$ ). Based on Figures $5 \mathrm{a}$ and $5 \mathrm{~b}, \mathrm{ME}$ of bengkoang stimulated the production of both inflammatory cytokines TNF- $\alpha$ and IL-6, whereas the nonpolar extract (PEE) and semi-polar fraction (EAF) of bengkoang reduced the levels of both TNF alpha and IL-6. In contrast, all of the bengkoang extracts decreased the production of the anti-inflammatory cytokine IL-10 (Figure 5c). 
The effect of PEE, ME, and EAF of bengkoang on cytokine production by lymphocyte cells was investigated. As shown in Figures 5a and 5b, ME of bengkoang can stimulate the production of both TNF- $\alpha$ and IL- 6 , whereas nonpolar extract (PEE) containing $\beta$-sitosterol and a semi-polar fraction (EAF) of bengkoang containing daidzein decrease both levels of TNF- $\alpha$ and IL-6. This finding is in line with those of a prior study that $\beta$-sitosterol reduced the expression of inflammatory cytokines, such as TNF- $\alpha$ and IL-6. Other research failed to demonstrate an anti-inflammatory effect of $\beta$ sitosterol, such as IL-10 upregulation (Bharanishankar et al., 2019; Yang et al., 2019; Calpe-Berdiel et al., 2007). The current results showed that, compared with the control group, the ME, PEE, and EAF of bengkoang decreased IL-10 production slightly (Figure 5c). IL-10 is an antiinflammatory cytokine, a product of the Th2 lymphocyte subpopulation. It has two main functions: inhibiting the production of several types of cytokines, such as TNF, and inhibiting the function of macrophages and dendritic cells in helping to activate T cells so that they act as an immunosuppressant (Iyer and Cheng, 2012). In addition, the isoflavone daidzein suppresses the production of cytokines such as IL-12, IL-6, and TNF- $\alpha$ but does not affect IL-10 and IL-1 $\beta$ (Yum et al., 2011). This study shows that the ME of bengkoang has an immunostimulant effect in vitro. Further investigation on the effect of immunomodulators in vivo is needed to determine its effect on innate and adaptive immune responses systemically.

\section{CONCLUSION}

This study showed that PEE, ME, and EAF of bengkoang could increase the non-specific immune response (phagocytosis) but has a lesser effect on the specific immune response (lymphocyte proliferation). The ME of bengkoang has an immunostimulant effect by increasing the levels of the inflammatory cytokines TNF- $\alpha$ and IL- 6 and decreasing those of the anti-inflammatory cytokine IL-10.

\section{ACKNOWLEDGEMENT}

This study was supported by the Research Grant of Collaborative Research of Lecturers and Doctoral Students (No. 43.05.04/UN1/FFA1/SET.PIM/PT/2019) Faculty of Pharmacy, Universitas Gadjah Mada, Indonesia. Authors also thank Prof. Takuya Sugahara from Ehime University for collaboration in this research.

\section{REFERENCES}

Abbas, A.K., Lichtman, A.H., Pillai, S., 2018. Cellular and molecular immunology e-Book, Ninth, Elsevier, Philadelphia.

Aderem, A., Ulevitch, R.J., 2000. Toll-like receptors in the induction of the innate immune response. Immunol. Lett. 406, 782-787.

Bharanishankar, S., Vishnupriya, V., Ponnulakshmi, R., Gayathri, R., Madhan, K., Shyamaladevi, B., Selvaraj, J., 2019. Effects of beta-sitosterol on inflammatory cytokines in high-fat diet-fed type-2 diabetic rats. Drug Invent. Today. 12, 906-909.

Calpe-Berdiel, L., Escolà-Gil, J.C., Benítez, S., Bancells, C., González-Sastre, F., 2007. Palomer X, Blanco-Vaca F. Dietary phytosterols modulate T-helper immune response but do not induce apparent antiinflammatory effects in a mouse model of acute, aseptic inflammation. Life Sci. 80, 1951-1956.

Champion, J.A., Walker, A., Mitragotri, S., 2008. Role of particle size in phagocytosis of polymeric microspheres. Pharm. Res. 25, 1815-1821.

Desjardins, M., Griffiths, G., 2003. Phagocytosis: Latex leads the way. Curr. Opin. Cell Biol. 15, 498-503.

Dwiecki, K., Neunert, G., Polewski, P., Polewski, K., 2009. Antioxidant activity of daidzein, a natural antioxidant, and its spectroscopic properties in organic solvents and phosphatidylcholine liposomes. J. Photochem. Photobiol. B, Biol. 96, 242-48.

El-gamal, Y.M., Elmasry, O.A., El-ghoneimy, D.H., 2011. Soliman IM. Immunomodulatory effects of food. Egypt J. Pediatr. Allergy Immunol. 9, 3-13.

Findlay, V.L., Munday, B.L., 2000. The immunomodulatory effects of levamisole on the nonspecific immune system of Atlantic salmon, Salmo salar L. J. Fish Dis. 23, 369378.

Iyer, S.S., Cheng, G., 2012. Role of interleukin 10 transcriptional regulation in inflammation and autoimmune disease. Crit. Rev. Immunol. 32, 23-63.

Jantan, I., Ahmad, W., Bukhari, S.N.A., 2015. Plantderived immunomodulators: An insight on their preclinical evaluation and clinical trials. Front. Plant Sci. 6, 1-18.

Jensch, B.E., Pressinotti, L.N., Borges, J.C.S., Da Silva, J.R.M.C., 2006. Characterization of macrophage phagocytosis of the tropical fish Prochilodus scrofa (Steindachner, 1881). 
Aquaculture. 251, 509-515.

Kaminogawa, S., Nanno, M., 2004. Modulation of immune functions by foods. Evid. Based Complement. Alternat. Med. 1, 241-50.

Kumalasari, I.D., Nishi, K., Harmayani, E., Raharjo, S., Sugahara, T., 2013. Effect of bengkoang (Pachyrhizus erosus) fiber extract on murine macrophage-like J774.1 cells and mouse peritoneal macrophages. J. Funct. Foods 5, 582-589.

Kumalasari, I.D., Nishi, K., Putra, A.B.N., Sugahara, T., 2014. Activation of macrophages stimulated by the Bengkoang fiber extract through toll-like receptor 4. Func. Food 5, 1403-1408.

Li, G.F., Liu, L.B., Tan, Y.L., Liu, L.Z., Deng, H.Z., Wan, H., Zhong, W.Z., Chen, S.J., 2011. In vitro effect of levamisole on the cell viability, phagocytosis and respiratory burst of Barbel chub (Squaliobarbus curriculus) macrophages. Aquac. Nutr. 17, e263-270.

Lukitaningsih, E., 2012. Phytosterol Content in Bengkoang (Pachyrhizus erosus). Pharmacon. 13, 47-54.

Lukitaningsih, E., Ulrike, H., 2014. Bioactive compounds in Bengkoang (Pachyrhizus erosus) as antioxidant and tyrosinase inhibiting agents. Indonesian. J. Pharm. 25, 68-75.

Maji, A.K., Mahapatra, S., Banerjee, D., 2014. In-vivo Immunomodulatory potential of standardized Pueraria Tuberosa extract and its isoflavonoids. Int. J. Pharm. Pharm. Sci. 6, 861-867.

Muralidharan, S., Mandrekar, P., 2013. Cellular stress response and innate immune signaling: Integrating pathways in host defense and inflammation. J. Leuko. Biol. 94, 1167-1184.

Noman, A.S.M., Hoque, M.A., Haque, M.M., Pervin, F., Karim, M.R., 2007. Food chemistry nutritional and anti-nutritional components in Pachyrhizus erosus L.Uber. Food Chem.
102, 1112-1118.

Nurrochmad, A., Ikawati, M., Sari, I.P., Murwanti, R., Nugroho, A.E., 2015. Immunomodulatory effects of ethanolic extract of Thyphonium flagelliforme (Lodd) blume in rats induced by cyclophosphamide. J. Evid. Based. Complementary Altern. Med. 20, 167-172.

Ray, A., Dittel, B.N., 2010. Isolation of mouse peritoneal cavity cells. J. Vis. Exp. 35, 9-11.

Schepetkin, I.A., Quinn, M.T., 2006. Botanical polysaccharides: Macrophage immunomodulation and therapeutic potential. Int. Immunopharmacol. 6, 317-33.

Sharma, A., Rangari, V., 2016. Immunomodulatory activity of methanol extract of Adansonia digitata L. Trop. J. Pharm. Res. 15,19231927.

Tsai, W.J., Chen, Y.C., Wu, M.H., Lin, L.C., Chuang. K.A., Chang, S.C., Kuo, Y.C., 2008. Seselin from Plumbago zeylanica inhibits phytohemagglutinin (PHA)-stimulated cell proliferation in human peripheral blood mononuclear cells. J. Ethnopharmacol. 119, 67-73.

Wahdaningsih, S., Wahyuono, S., Riyanto, S., Murwanti, R., 2018. Antioxidant activity of red dragon fruit peel (Hylocereus polyrhizus (F.A.C. weber) britton and rose) isolates using 2,2-diphenyl-1-picrylhydrazyl method. Asian J. Pharm. Clin. Res. 11, 124128.

Woronzoff-Dashkoff, K.K., 2002. The WrightGiemsa stain: Secrets revealed. Clin. Lab. Med. 22, 15-23.

Yang, Q., Yu, D., Zhang, Y., 2019. $\beta$-Sitosterol attenuates the intracranial aneurysm growth by suppressing TNF- $\alpha$-mediated mechanism. Pharmacology. 104, 303-311.

Yum, M.K., Jung, M.Y., Cho, D., Kim, T.S., 2011. Suppression of dendritic cells' maturation and functions by daidzein, a phytoestrogen. Toxicol. Appl. Pharmacol. 257, 174-181. 